\title{
Growing Old in the Gulag Gerald Niles
}

$A_{\text {miseries of material existence. Having been in prison since I was young, }}^{\text {ccording to Bhagavad Gita, birth, aging, disease and death are four }}$ I cannot compare living and dying in the gulag to the same experience in free world, but it is known - at least amongst prisoners - that the miseries of aging (Nagelsen and Huckelbury, 2006), disease (Dey, 2007; Norman, 2010; Diorio, 2016; Convict, 2017) and death (Bowser, 2007; Rothwell, 2010; Becerra, 2015) are amplified behind bars.

When health problems hit older prisoners, the authorities claim care is available. Where I am incarcerated, many prison operations and services, including those related to health care, are contracted out (Reutter, 2007). The contractors are in the business of making profit, not saving lives (Hylton, 2007). It has been my experience, sitting in a cell in the United States, that minimal treatment is often rendered. When things get serious, the game can become deadly (Zielbauer, 2007). I have witnessed prisoners having heart attacks and dying because medical responders have dead batteries in atrial fibrillation devices, that is if they even remember to bring along such equipment when a life is in need of saving.

Elderly prisoners everywhere can relate to and tell of their own experiences, as in the following example. On 6 September 2014, in Jefferson Prison located in Monticello, Florida, a prisoner suffered textbook symptoms of ischemic stroke. His right side was numb, he drooled, could not lift his right hand, nor walk. His speech was slurred, but his thoughts were clear as a bell. Contractor Corizon, which has since changed its name to Centurion, dispatched a nurse who came to the dorm with a wheelchair. Prisoners helped situate the victim in the wheelchair.

At the medical clinic, the nurse was unable to reach the on-call emergency physician and the only empty bunks in the infirmary were broken. The nurse declared, "you'll be all right", and sent the victim back to the dorm. Unable to walk, a fellow prisoner got him back to the dorm in the wheelchair where he was left to fend for himself.

Later, next shift, the dorm guard saw something obviously wrong and notified another nurse about the dire situation. The nurse took the victim to the clinic, contacted the emergency room physician, did an EKG and determined that a stroke had taken place. It was too late to render emergency treatment. A bunk in the infirmary was propped up on milk crates and the victim was admitted for observation. While the prisoner survived and lived 
to sue the contractor, the authorities denied the victim even suffered a stroke. The Court ordered an MRI at the Tallahassee Regional Memorial Hospital Stroke Unit. The MRI showed conclusive proof of a stroke. The contractor began offering settlements to avoid a jury verdict of cruel and unusual punishment, along with hefty punitive damages.

Nobody should have to suffer similar incidents. Prison medical contracts should be outlawed. Older prisoners become more vulnerable to physical assaults, theft, robbery and even rape (Threinen, 2017). As prisoners get older, we require more time to eat due to tooth loss or inadequate dental care. We become sick and fall down easier. Generally, older prisoners have it rougher than younger prisoners. We (old folks) cannot move as fast as we once did.

Growing old in the gulag is unbearable and if the state will not move to alleviate suffering, do prisoners need to start advocating for the law to permit voluntary euthanasia to point out the absurdity of keeping seniors behind bars in the name of 'public safety' and 'justice'? Sometimes we just get tired and want to lay down. Our relatives and sources of support pass away. What do we live for? If ever freed, for what? Freed to the giant prison house known as the material free world?

In a context where compassionate release on medical grounds (Muise, 2013; Muise, 2015) is denied even when available on paper (Lennon, 2015; Piché, 2015), I do not have any solutions to offer for the problems faced by older prisoners short of the abolition of prisons, which would at least cure a lot of ills associated with the violence of incarceration (Mathiesen, 2006; also see Drucker, 2011).

\section{REFERENCES}

Becerra, Victor (2015) “Check Out Time”, Journal of Prisoners on Prisons, 24(1): 4344.

Bowser, Ed (2007) "When Death Comes Knocking”, Journal of Prisoners on Prisons, 16(2): 31-34.

Convict, Joe (2017) “Mountain Institution”, Journal of Prisoners on Prisons, 26(1\&2): 247-260.

Dey, Eugene (2007) "Hepatitis C and the California Prisoner", Journal of Prisoners on Prisons, 16(2): 53-58.

Diorio, Charles N. (2016) "MCI-Shirley, Hepatitis C \& Me", Journal of Prisoners on Prisons, 25(1): 39-42. 
Drucker, Ernest (2011) A Plague of Prisons: The Epidemiology of Mass Incarceration in America, New York: The New Press.

Hylton, Wil S. (2007) "Sick on the Inside: Correctional HMOs and the Coming Prison Plague", in Tara Herivel and Paul Wright (eds.), Prison Profiteers: Who Makes Money from Mass Incarceration, New York: The New Press, pp. 179-203.

Lennon, John J. (2015) "Lenny's Last Days...in Attica", Journal of Prisoners on Prisons, 24(1): 45-48.

Nagelsen, Susan and Charles Huckelbury (eds.) (2006) Special Issue: Aging in Prisons, Journal of Prisoners on Prisons, 14(2), 56 pages.

Mathiesen, Thomas (2006) Prison on Trial (third edition), London: Waterside Press.

Muise, Timothy (2015) "Why Compassionate Release? A Follow-up to "What is Compassionate Release?"”, Journal of Prisoners on Prisons, 24(1): 65-69.

Muise, Timothy (2013) "What is Compassionate Release?", Journal of Prisoners on Prisons, 22(2): 46-49.

Norman, Charles (2010) "Fighting the Ninja", Journal of Prisoners on Prisons, 19(1): 35-48.

Piché, Justin (2015) "Reflections on the Contributions of Peter Collins and the Death of Humanity Behind Bars", Journal of Prisoners on Prisons, 24(1): 84-86.

Reutter, David M. (2007) "Florida's Private Prison Industry Corporation Under Siege", in Tara Herivel and Paul Wright (eds.), Prison Profiteers: Who Makes Money from Mass Incarceration, New York: The New Press, pp. 141-156.

Rothwell, Michael (2010) “Check Out Day”, Journal of Prisoners on Prisons, 19(1): 10-17.

Threinen, David W. (2017) “Dorchester Institution”, Journal of Prisoners on Prisons, 26(1\&2): 74-79.

von Zielbauer, Paul (2007) "Private Health Care in Jails Can Be a Death Sentence", in Tara Herivel and Paul Wright (eds.), Prison Profiteers: Who Makes Money from Mass Incarceration, New York: The New Press, pp. 204-227.

\title{
ABOUT THE AUTHOR
}

Gerald Niles has been incarcerated in Florida for decades. His publications in the Journal of Prisoners on Prisons include "Submission, Subservience, 'Model Inmates', and the Fear Factor: Observations from a Sweet Kamp Down Florida Way" (Niles, 1993) and "A Decade of Diesel Therapy in the Floriduh Gulag" (Niles, 1999). He can be reached at the address below.

\author{
Gerald Niles \\ Jefferson Correctional Institution \\ 1050 Big Joe Road \\ Monticello, Florida 32344 \\ USA
}

